IRA-International Journal of Education \&

Multidisciplinary Studies

ISSN 2455-2526; Vol.17, Issue o3 (Q3, 2021)

Pg. no. 166-172.

IRA Academico Research

\title{
Investigation on Autonomous Learning of Foreign Language and Countermeasures for Constructing an Autonomous Learning Platform
}

\author{
Xu Fang ${ }^{1 \#}$, Tan Cuifeng ${ }^{2}$ (D), Zhang Yiran ${ }^{3}$ \\ 1,2,3 School of Foreign Studies, Yangtze University, Jingzhou, Hubei, China. \\ \# corresponding author \\ Type of Work: Peer Reviewed. \\ DOI: 10.21013/jems.v17.n3.p7 \\ DOI URL: https://dx.doi.org/10.21013/jems.v17.n3.p7
}

\section{How to cite this paper:}

Fang, X., Cuifeng, T., Yiran, Z. (2021). Investigation on Autonomous Learning of Foreign Language and Countermeasures for Constructing an Autonomous Learning Platform. IRA-International Journal of Education \& Multidisciplinary Studies (ISSN 2455-2526), 17(3), 166-172. DOI: https://dx.doi.org/10.21013/jems.v17.n3.p7

(C) IRA Academico Research.

(c) EY-No 4.0 International License subject to a proper citation to the publication source of the work.

Disclaimer: The scholarly papers as reviewed and published by IRA Academico Research are the views and opinions of their respective authors and are not the views or opinions of IRA Academico Research. IRA Academico Research disclaims any harm or loss caused due to the published content to any party.

IRA Academico Research is an institutional publisher member of Publishers International Linking Association Inc. (PILA-CrossRef), USA. IRA Academico Research is an institutional signatory to the Budapest Open Access Initiative. Hungary advocating the open access of scientific and scholarly knowledge. IRA Academico Research is a registered content provider under Open Access Initiative Protocol for Metadata Harvesting (OAl-PMH).

The journal is indexed \& included in WorldCat Discovery Service (USA), CrossRef Metadata Search (USA), WorldCat (USA), OCLC (USA), Open J-Gate (India), EZB (Germany) Scilit (Switzerland), Airiti (China), Bielefeld Academic Search Engine (BASE) of Bielefeld University, Germany, PKP Index of Simon Fraser University, Canada.

Tan Cuifeng (10/0000-0001-9711-1265 


\begin{abstract}
The connotation of autonomous learning is expanding as time progressed. Under the background of "Internet plus" education, colleges and universities pay more attention to the application of network teaching resources in teaching. Universities intensified the reform of college English teaching and built platforms for autonomous learning, supplementing the shortcomings of English classroom teaching and improving students' autonomous learning ability. This paper takes local college students as the research object, makes an investigation and analyzes the situations of college students autonomous learning. The findings suggested that the following questions are addressed: lack of motivation of autonomous learning, lack of self-exploration of effective learning strategies, lack of the ability of multiple interactions. This paper will give relevant strategies for building a platform for college English autonomous learning to promote and cultivate students' independent learning ability of foreign languages.
\end{abstract}

Keywords: foreign language autonomous learning; current situation research; autonomous learning platform; countermeasure research

\title{
1. The Importance of Autonomous Learning
}

Cultivating autonomous learning ability is one of the strategic themes of China's educational reform and development. The newly issued document "The Requirement for College English teaching" (Higher Education Department of the Ministry of Education, 2007) emphasized on the goal of college English teaching is to cultivate students' comprehensive English ability. It is so that they will be able to communicate effectively in social interactions and enhance independent learning ability and improve overall cultural literacy to meet the needs of social development and international exchanges.

Secondly, cultivating comprehensive talents with innovative spirit and practical ability is a characteristic of quality-oriented education and a new challenge that education must combine with knowledge economy and talent training. And it is the ability to learn independence that is the foundation of cultivating an innovative spirit and practical ability.

Finally, since the 20th century, lifelong learning has been the most influential, wide-spreading and most vigorous educational belief in international society. And develop the ability of autonomous learning is an important foundation for lifelong learning. The strength of autonomous learning ability not only affects academic performance but also is a prerequisite for lifelong learning for individuals to survive (Pang Guowei, 2001). Because of this, English educators in my country regard the cultivation of autonomous learning as one of the important teaching goals and include them in the syllabus, striving to explore autonomous learning models and effective ways to promote the development of autonomous learning capabilities.

\section{Research Design}

\subsection{Questionnaire Survey}

The students of a comprehensive university in Hubei province were investigated by cluster-sampled with the autonomous learning questionnaires designed by the authors. 500 questionnaires were collected and 450 are valid. The questionnaire uses Likert scale methods and divides into three sections: personal information (Including grade, major and gender); the current situations of foreign language autonomous learning (Including learning attitudes, learning strategies and communicative interaction); students' evaluation of their own foreign language autonomous learning status.

\subsection{Interview}

12 students from different majors were selected to survey in-depth interviews to gain a deeper understanding of students' actual self-learning process. The interview mainly started from the specific use of foreign language selflearning strategies, such as vocabulary strategies, reading strategies, listening strategies, speaking strategies, and writing strategies. The specific questions are as follows:

1. How much time do you spend on self-study of foreign languages every day? (Time) 
2. What method do you often use to memorize words? (Word)

3. Do you practice listening every day after class? (Listening)

4. Have you read the original English works? (Reading)

5. Do you often write in English? (Writing)

6. Will you deliberately communicate with others in oral English? (Speaking)

7. In the process of English learning, which section is the most difficult to learn?

8. Make an evaluation of your own self-directed learning.

\section{Research Results}

\subsection{The Validity and Reliability of the Questionnaire}

The discrimination of the questionnaire was tested by SPSS 20.2 version. Regarding the coefficient of total reliability, if the $\alpha$ factor $>0.8$, the reliability is high, if it is between $0.7-0.8$, the reliability is good; if it is between $0.6-0.7$, the reliability is acceptable, The reliability of this questionnaire $\alpha$ coefficient $=0.823$, indicating that the reliability is very high.

\subsection{Duration of Self-directed Learning}

According to the questionnaire statistics, "students spend more than 5 hours in autonomous foreign language learning every day" accounted for $7.41 \%$, "3 to 4 hours of autonomous foreign language learning" accounted for $9.79 \%$, and "foreign language independent learning for $2-3$ hours" accounted for $13.71 \%$, "Foreign language selflearning for 1-2 hours" accounted for 42.47\%, "foreign language autonomy for less than 1 hour" accounted for $26.62 \%$, indicating that most students have a short period of foreign language self-learning and take less energy on it.

\subsection{Current Situations of Autonomous Learning of Foreign Languages}

\subsubsection{Lack of Motivation of Autonomous Learning}

The evidence from this study suggests that most college students appear to be very passive in the process of learning English. $60 \%$ of students believe that foreign language learning is not important, especially non-English majors who think they only need to learn public English and get credits; $73 \%$ of students expressed that they are not interested in English learning. Even if there will be pressure on English tests and final exams, the learning driven by these pressures is passive and negative. So, in the process of learning English, students usually only complete the learning tasks arranged by the teacher. However, these tasks arranged by the teacher are often more basic tasks in the textbook, which is narrow for them to accept the higher challenge. Even if students understand that they have many deficiencies in English learning, they will not take the initiative to find out and fill up the vacancies, which leads to low quality of college English teaching.

\subsubsection{Lack of Effective Learning Strategies}

In terms of learning strategies, most students do not have the habit of formulating foreign language learning plans and evaluating autonomous learning; in terms of training English skills, 82\% of students rarely use listening, speaking, reading and writing skills. When it comes to foreign language autonomy learning, most students focus on the vocabulary memory module. It is unrealistic to simply equate memorizing words with foreign language learning; in terms of emotional management, some students will feel frustrated due to the poor self-learning effect and are vulnerable to negativity; emotional influences, such as low self-esteem, improper handling of romantic relationships. These show that most students lack the ability to self-explore effective learning strategies, including self-planning strategies, self-monitoring strategies and self-emotion management strategies. 


\subsubsection{Lack of the Ability of Multiple Interactions}

Finally, students lack the ability of multiple interactions, including teacher-student interaction, student-student interaction, and human-computer interaction. Although the modern new teaching model emphasizes two-way output, there is still a traditional one-way teaching model in actual classrooms. Some teachers confuse independent learning and self-study. And some are completely out of the teacher's responsibilities and obligations, just let selfstudy slide. It is a common practice that some teachers serve as a guide in cultivating students' self-learning ability without effective guidance on students' study habits and learning methods and observation of the changes in students' thoughts and psychology in the process of autonomous learning. Over time, students lose interest and motivation in learning. Although the starting point and ideas are positive, they turned out to be counterproductive. Moreover, the communication between teachers and students is limited to the classroom, lack of extracurricular communication. And student-student interaction is limited to their respective dormitory circles or social circles. Finally, with the booming of the Internet, online learning has become an important part of foreign language learning. College students have changed from passive acquirers of knowledge to active ones. However, in the face of massive learning resources, some lack critical thinking, the ability to distinguish and filter information, and the ability to share information. In interviews, most students said that the Internet is highly seductive and easily dispersed independent learning. Therefore, to some extent, human-computer interaction has not yet formed a harmonious interactive environment.

\section{Current Situation Analysis}

\subsection{Reasons for Lacking of Motivation}

The source of motivation for independent learning mainly comes from the future of personal development. As a language tool, foreign languages are intersected with most subjects. However, most people do not understand the skills required by their profession and lack the consciousness of cultivating comprehensive talents in the new informational context, which leads many students not to pay much attention to foreign language learning after entering the university. In addition, after entering the university, they are too attached to the traditional teaching mode and rely on the guidance and supervision of teachers. And they believe that language learning only needs to follow the teachers' pace. As a result, they can't adapt to the university's new autonomous learning model, gradually falling into the disordered state of English learning--lack of motivation, awareness and habits of autonomous learning. In addition, the surrounding---lazy style lacks a strong learning atmosphere that stimulates students' enthusiasm and initiative in autonomous learning.

\subsection{Reasons for Lacking of Effective Learning Strategies}

\subsubsection{Resource Management Strategy}

The learning content and form are not rich enough. The textbook is the main material for students to learn English. But the content in the textbook is limited so that the knowledge that students can accept is also very limited. Although some schools have built English online learning platforms, the role of the platform has not been fully utilized. For example, the school will supplement some English learning resources on the platform, such as audio resources, video resources, magazines and newspapers, etc. These resources will be placed on the platform for a long time without updating, which will greatly reduce the students' English learning Interest and enthusiasm. In addition, some students will pay attention to the resources on the platform, but the frequency of attention is not high, resulting in low utilization of resources. As a result, the content that students learn is still very single, and the learning form is not rich enough. Therefore, in order to improve the autonomy of college students in learning English, schools also need to increase the construction of English autonomous learning platforms to create a good learning platform for students to learn English more efficiently.

\subsubsection{Affective Strategy}

Emotion is a crucial factor that affects foreign language learning. But foreign language education research has long focused on knowledge transfer and largely ignored the emotional level (Perrin \& Linnenbrink-Garcia 2014; Xu Jinfen 2020). Wen Qiufang, Wang Lifei and others pointed out that the study of autonomous learning strategies in 
emotional communication in China is relatively weak. Scholars generally agree that positive emotions can help students improve their ability to pay attention to new things, encourage them to absorb more language input information, help expand their thinking, broaden their horizons, and stimulate action, making the process of foreign language learning easier and more effective (Maclnytyre \& Gregersen 2012). In fact, most students accept the theories of autonomous learning, but in the process of a truly autonomous learning environment, a considerable number of people will experience a vacuum in learning and do not know how to set goals? How to arrange the schedule? How to face difficulties? How to evaluate the deficiencies of autonomous learning and adjust learning strategies in time? Therefore, in the case of full autonomy, there is no way to start, and students are prone to anxiety and even negative learning emotions, which ultimately leads to poor self-learning effects. Language learning is a complex, changeable, time-consuming and labour-intensive process. During the learning process, there are both positive emotions that can promptly self-adjust when encountering setbacks, and negative emotions of self-rejection due to failure to overcome learning difficulties. To a large extent, students' emotional instability and polarity have a great impact on the effect of autonomous learning.

\subsection{Reasons for Lacking of Multiple Interactions}

Multi-interaction is actually an ability to independently create opportunities for foreign language use and foreign language learning (Xu Jinfen, 2020). With the continuous development of Internet technology, the interactive channels for foreign language learners have gradually diversified, and the learning ecological environment has changed (Chen Jianlin, 2006). Faced with a large number of learning resources, students will be in a state of confusion due to the lack of efficient information search capabilities; most people lack control over various entertainment information, which distracts their learning efforts. At the same time, it is precise because of the changes in the learning ecological environment that there is a lack of communication and cooperation between students and teachers, and between students and students.

\section{Recommendations}

\subsection{Learner}

Autonomous foreign language learners must have clear learning objectives, scientifically plan to learn content, and explore effective learning strategies. Due to the complexity, dynamics and long-term nature of the learning process, the use of learning strategies will be affected by various factors, including subjective factors and Objective factors, so in the process of foreign language autonomous learning, students must constantly practice, monitor and adjust their own learning, retain effective learning strategies and cultivate the ability to self-explore effective learning strategies. This ability is not only suitable for foreign language autonomous learning, but also for other curriculum and lifelong learning. So, it is necessary for students to take the initiative to study cooperatively with others, actively exchange learning experiences, and discuss learning problems together. And it is also helpful to accept and adjust emotions correctly with a peaceful mind, such as maintaining a rational understanding, venting to others, and actively self-suggesting. While mastering foreign language knowledge, we must also cultivate the emotions, attitudes and values and participate in the construction of a community with a shared future for mankind and communicate with people from different cultural backgrounds in an open and tolerant manner.

\subsection{Teacher}

Teachers are the instructors, motivators and consultants of college students' English autonomous learning. Under the premise of recognizing the differences in students' English learning ability and combining teaching plans and curriculum requirements, teachers are supposed to take advantage of the practical function of media, giving students good guidance in and out of class, helping students set up good learning goals, formulating learning plans, guiding students' learning strategies and methods, providing students with effective online learning resources, and monitoring students' learning progress. At the same time, treating students with an attitude of equality, democracy, care and understanding, helping them analyze problems and overcome difficulties, and guiding them to realize the great role of perseverance, perseverance, persistence and other non-intellectual factors in learning are equivalent to developing awareness of autonomous learning. In short, teachers should attach the importance of cultivating students' sense of autonomous put it into practice. 


\subsection{Countermeasures for Self-learning Platform Construction}

Educational ecology theory pays special attention to the learning context and learning process. It believes that individuals can actively perceive and use the supplies in the learning environment to promote language learning (Chapelle, 2009). Therefore, the school must create an external environment for students to learn independently. For example, building a foreign language autonomous learning platform, and implanting excellent learning resources from major network platforms into the school. So that students can choose what they are interested in learning to improve their learning. For example, there are specialized English courses in "MOOC Academy", which contain various types of English courses, such as college English vocabulary, financial English to see the world, English literature guide, foreign economic and trade English correspondence, British society and culture, international communication English, etc. Implanting the excellent courses into the school's self-learning platform gives students more chances to, broaden their horizons and improve the effectiveness of their learning.

In addition, the most important thing in foreign language learning is the output process. So the school can organize English knowledge learning lectures, English learning experience sharing sessions, English subject competitions, such as reading, translation, writing, speech. Hold class activities by selecting specific topics that students are interested in, such as movies, travel, love, etc. Finally, carry out foreign language corner activities for students of all majors.

In traditional college English teaching, there is very little interaction between teachers and students, which is one reason why students are not motivated to learn. When the school builds an autonomous English learning platform for college students, it can add a learning interactive module to provide a platform for communication among students, as well as between teachers and students. For example, teachers can initiate topic discussions on the platform, such as the comparison of Chinese and Western civilizations, where students can make their own speeches, express their opinions, and express their ideas. Teachers can also participate in students' discussions and give appropriate pointers to areas where students do not understand well. Another example is that college students are about to find a job, and some companies will test their ability to use English in the workplace when recruiting staff. Therefore, students can also discuss workplace English related content in this module, and practice workplace English under the guidance of teachers to increase the success rate of students' employment. Moreover, when students enter the workplace in the future, this knowledge will also be of great help to students and will be very beneficial to students' future growth. This can not only avoid the embarrassment of face-to-face communication, but also enable teachers to better understand students' ideas, and can also shorten the distance between teachers and students, which is of great significance for promoting students' progress in English learning.

\section{Conclusion}

Obtaining the core power needed for self-development from the vast knowledge, cultivating the ability to learn independently and mastering scientific learning methods are undoubtedly the skills that every modern person must possess. The American futurist Alvin Toffler once said: "In the future, illiterate people will no longer be illiterate people, but people who have not learned how to learn." For college students, learning is by no means limited to schools and classrooms. It is necessary to focus on the cultivation of independent learning ability and the establishment of a lifelong learning consciousness. If universities can effectively use network resources, focus on the learning needs of students, plant excellent resources for autonomous learning platforms, increase student interaction modules, and promote interaction between teachers and students and between students and students. Then college English education will appear prosperous scene.

\section{References:}

[1]. Chapelle, C. A. (2009). The relationship between second language acquisition theory and computer-assisted language learning [J]. The Modern Language Journal. 93( S1): 741-753.

[2]. Pekrun, R. \& Linnenbrink-Garcia, L.(2014). International Handbook of Emotions in Education [M]. New York: Routledge.

[3]. MacIntyre, P. \& Gregersen, T. (2012). Emotions that facilitate language learning: The positive-broadening power of the imagination [J]. Studies in Second Language Learning and Teaching. 2( 2) : 193-213.

[4]. Department of Higher Education, Ministry of Education. (2017). Teaching Requirements for College English Courses [Z]. Shanghai Foreign Language Education Press. 
[5]. Guowei Pang. (2001). On students' autonomous learning [J]. Journal of East China Normal University (Education Science Edition). 20(2): 78-83.

[6]. Jianlin Chen. (2006). The organic integration of computer networks and foreign language courses under the new mode of college English teaching-An ecological investigation of the concept of computer-assisted foreign language teaching [J]. Audio-visual Foreign Language Teaching. (6): 3-10.

[7]. Jinfen Xu. (2020). On the Psychological Research of Foreign Language Teachers [J]. Foreign Languages Journal. (3): 56-62. 